\title{
Seismic hazard of the western Makran subduction zone: insight from mechanical modelling and inferred frictional properties
}

\author{
Sepideh Pajang ${ }^{\mathrm{a}, \mathrm{b}, 1}$, Nadaya Cubas ${ }^{\mathrm{b}}$, Jean Letouzey ${ }^{\mathrm{b}}$, Laëtitia Le Pourhiet ${ }^{\mathrm{b}}$, \\ Seyedmohsen Seyedalic ${ }^{\mathrm{c}}$ Marc Fournier ${ }^{\mathrm{b}}$, Philippe Agard ${ }^{\mathrm{b}}$, Mohammad Mahdi \\ Khatib $^{\mathrm{a}}$, Mahmoudreza Heyhat ${ }^{\mathrm{a}}$, Mohammad Mokhtari ${ }^{\mathrm{d}}$ \\ ${ }^{a}$ Geoscience department, University of Birjand, Birjand, Iran \\ ${ }^{b}$ Institut des Sciences de la Terre Paris, ISTeP UMR 7193, Sorbonne Universite, CNRS-INSU, \\ 75005 Paris, France \\ ${ }^{c}$ National Iranian Oil Company (NIOC), Tehran, Iran \\ ${ }^{d}$ International Institute of Earthquake Engineering and Seismology (IIEES), Tehran, Iran
}

\begin{abstract}
Western Makran is one of the few subduction zones left with a largely unconstrained seismogenic potential. According to the sparse GPS stations, the subduction is accumulating some strain to be released during future earthquakes. To enhance the seismic hazard assessment, we here propose to study the finite deformation of the western Makran accretionary wedge. Mechanical modelling is used to retrieve the spatial variations of the frictional properties of the megathrust, and discuss its seismogenic potential. To do so, we first build a structural map along the Iranian part of the Oman Sea and investigate three N-S seismic profiles. The profiles are characterized by a long imbricated thrust zone that takes place at the front of the wedge. A diapiric zone of shallow origin lies in between the imbricated zone and the shore. Along the eastern and western shores, active listric normal faults seem to root down to the megathrust. Eastern and western domains have developed similar deformation, with three zones of active faulting: the normal faults on shore, thrusts ahead of the mud diapirs, and the frontal thrusts. On the contrary, no normal faults are identified along the central domain, where a seamount is entering into subduction. Two mechanical analyses are performed to retrieve the frictional prop-
\end{abstract}

Email address: sepideh.pajang@upmc.fr and sepideh.pajang@birjand.ac.ir (Sepideh Pajang) 
erties of the megathrust. We first apply the critical taper theory to constrain the pore fluid pressure of the wedge. We then apply the limit analysis on two selected profiles. Along the eastern profile, a transition from very low to extremely low friction is required to activate the large coastal normal fault $\left(\mu_{\text {deep }}^{\text {eff }}=0.01-0.06, \mu_{\text {middle }}^{\text {eff }}\right.$ $=0.003-0.012)$. To propagate the deformation to the front, an increase of friction along the imbricated zone is necessary $\left(\mu_{\text {front }}^{\text {eff }}=0.017-0.031\right)$. The method could not be applied on the incomplete western profile. However, since the deformation is similar to the eastern profile, the same transitions of friction are expected. The Central domain is also characterized by very low effective friction;but, the absence of normal fault does not allow to evidence any frictional transition.

Since dynamic effective friction coefficients are significantly lower than frictions at slow slip rate, the region of extremely low friction between the normal fault and the imbricated zone might reveal the location of a seismic asperity. The difference in deformation along strike would thus reveal the existence of two different asperities, one along the eastern domain and a second along the western domain. Since no earthquake have occurred in the region for, at least, the last 1000 years, an event of large magnitude may strike the Iranian Makran, in particular the Eastern domain. Keywords: Makran, Seismic hazard, Frictional properties, Mechanical modelling

\section{1. Introduction}

The $1000 \mathrm{~km}$ long Makran is one of the few subduction zones left with a largely unconstrained seismogenic potential. The region indeed lacks historical records due 4 to the sparsity of past settled population and is still poorly instrumented. However, 5 the development of Chabahar and Gwadar Ports, and the risk of potential tsunamis 6 for the region calls for a better hazard assessment. Along the Pakistani side, only 7 three significant events in 1756, 1851 and 1945 have been reported [1]. The last one, 8 with an estimated magnitude of $\mathrm{Mw}$ 8.1, is the only major event instrumentally 9 recorded so far [1] (Figure 1a). Along the Iranian side, one major event dated back to 1483 could be linked to the subduction [2], but its location and date are 11 strongly debated [3]. Recent geodetic and InSAR studies have shown that some 
accumulation of elastic strain along the plate interface is required to explain the velocity profiles on both the Pakistani and Iranian sides [4, 5, 6] (Figure 1b). All studies proposed a relatively strong coupling along eastern Makran (where the 1945 earthquake occurred), a decrease along the central part, and a possible increase westward. However, due to the sparsity of stations, large trench-coast distance, and limited constraints on slab dip, these studies were unable to constrain neither the along-dip nor the along-strike extent of possible coupled zones (e.g., [6]).

The Makran subduction zone is famous for its impressive $\sim 7.5 \mathrm{~km}$ thick and 400 $\mathrm{km}$ wide accretionary prism, half of it sub-aerial [11]. Large accretionary prisms have often been considered of limited seismic and tsunamigenic risk because of the ratestrengthening nature of their unconsolidated sediments $[12,13]$. This classical view, the particular dimension of the Makran prism, and the lack of historical earthquake led many authors to disregard the seismogenic potential of the area. However, the idea of limited extent of earthquakes to accretionary prisms was strongly challenged by the $2011 \mathrm{Mw} 9.0$ Tohoku-Oki and the $2004 \mathrm{Mw} 9.0$ Sumatra Andaman events (e.g., [14]).

According to heat flow measurements and modelling (e.g., [15]), lab experiments (e.g., [16]), drilling (e.g., [17]) or structural studies (e.g., [18, 19]), megathrust effective friction appears to differ significantly between aseismic or seismic areas. Megathrusts undergoing mostly aseismic deformation are indeed characterized by intermediate values of effective friction $(\mu \geq 0.1)$, whereas lower effective (or apparent) friction is found where major earthquakes occur $(\mu \sim 0.01-0.03)[15,18]$. Such differences in effective friction are significant enough to produce wedge segments with varying morphologies and deformation patterns. For instance, a wedge characterized by aseismic slip and thus intermediate friction along the megathrust will reach more easily its critical state generating internal deformation (e.g., [18]).

On the contrary, seismic asperities characterized by very low effective friction coefficients are expected to construct a stable wedge, impeding any internal deformation [18]. Moreover, the transition of effective friction coefficients from aseismic to seis- 


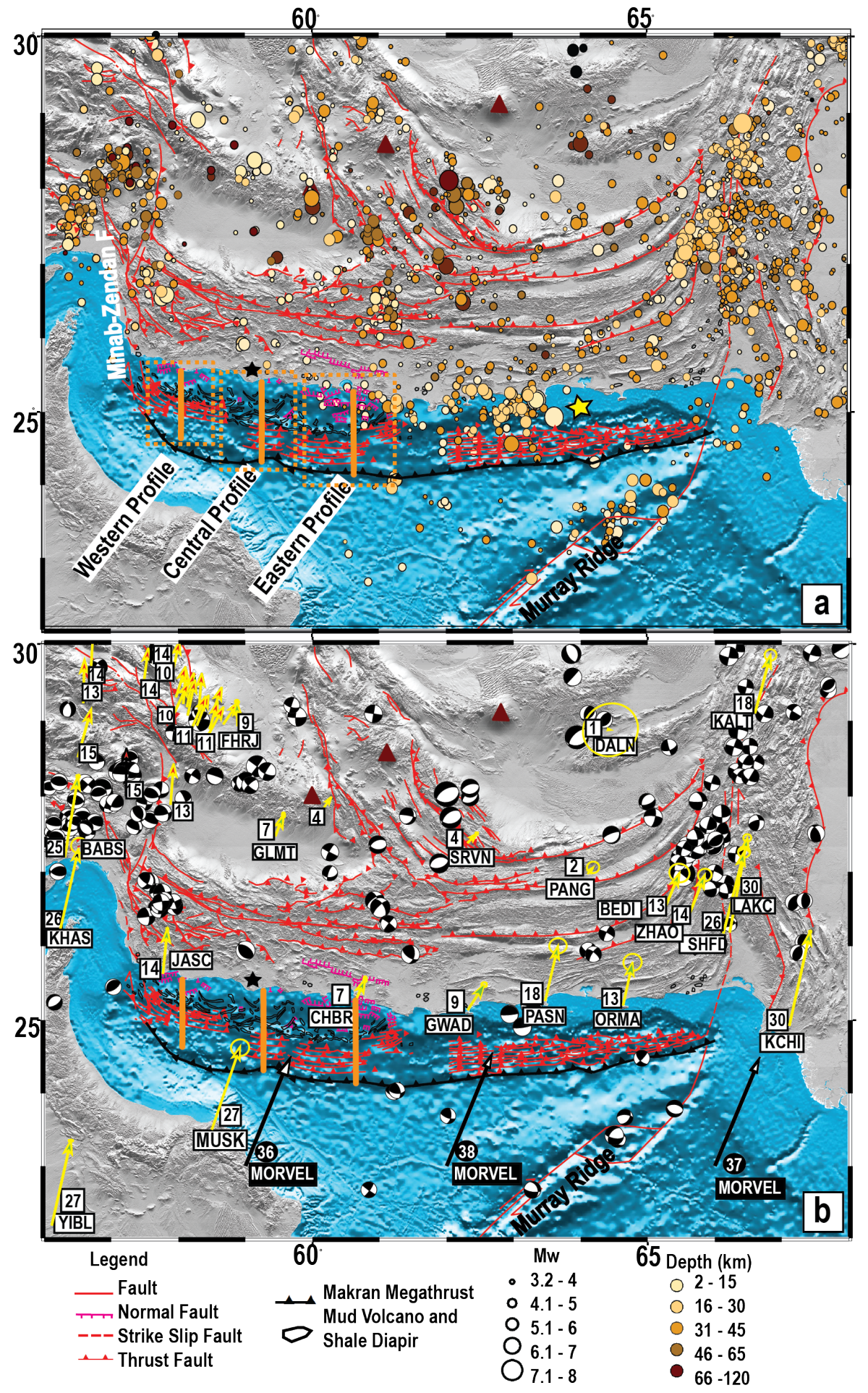

Figure 1: Seismo-tectonic map of Makran a. Seismicity, with earthquakes of magnitude $\geq 3.5$ from 1945 to 2013 shown as colored circles. Red lines indicate known faults, mud volcanoes are shown by black contours. Positions of active mud volcanoes within Pakistani side from [7]. Imbricate thrust faults in the Pakistanis side from Smith et al. [8] picked from MCS data (multichannel seismic reflection) and correlated with bathymetric data. On the Iranian side, mud volcanoes, imbricate thrust faults, and normal faults are picked from PC2000 data released by NIOC. The onshore well in Iran is indicated by black star and the $1945 \mathrm{Mw} 8.1$ earthquake by yellow star. Thick orange lines indicate the $2 \mathrm{D}$ seismic lines used in this study. Based on the structural analysis western Makran can be separated in three different structural domains (Western, Central and Eastern) which are identified by dashed-orange boxes. b. Relative motions with respect to stable Eurasia. Yellow arrows are GPS velocity vectors with 95 per cent confidence ellipses $[9,5]$; MORVEL velocities from DeMets et al. [10]. Focal mechanisms reported by gCMT. 
mic asperities can also induce activation of splay faults [19]. As a consequence, the deformation observed in the continental wedge brings information on the mechanical behavior of the megathrust [20].

The Western Makran accretionary prism appears as an ideal candidate to study and link the finite deformation with spatial variations of megathrust frictional properties and seismic behavior. We here propose to take advantage of seismic profiles released by NIOC along the whole Iranian side to improve the assessment of seismic and tsunamigenic hazards of the region. We first present a brief seismo-tectonic description of the region before describing selected seismic lines. We then conduct a mechanical study to retrieve the spatial variation of the frictional properties of the megathrust. Seismic and tsunamigenic hazards are finally discussed in the last section.

\section{Seismo-tectonic setting}

The Makran subduction, which started during Early Cretaceous, is located in between two major collisional zones, Zagros to the West, and Himalaya to the East [21]. Transitions to collisional domains are accommodated by two major strikeslip systems, the Ornach Nal fault to the East, and the Minab-Zendan fault to the West (Figure 1). Current motions recalculated from seafloor spreading rates and fault azimuths for the major plates show comparable along strike convergence rates increasing slightly from $35.5-36.5 \mathrm{~mm} / \mathrm{a}$ in western Makran to $39 \mathrm{~mm} / \mathrm{a}$ in the East [10] (Figure 1b).

The Makran accretionary wedge is about $400 \mathrm{~km}$ wide, two-thirds of it being located onshore to the North. A narrow (few kilometers wide) coastal belt along which normal faults and mud volcanoes are prominent separates the on- and offshore parts (e.g., [22, 21]). On its eastern side, the Makran accretionary prism accumulates up to $7.5 \mathrm{~km}$ of incoming sediments [11], brought by the Indus river and erosional portions of the growing prism. The incoming sediments consist of 3 $\mathrm{km}$ of Makran sands that are derived from the North [23]. They unconformably 
overlie $4 \mathrm{~km}$ of Himalayan turbidites derived from the Indus fan to the East [11].

There are no major river system providing sediment input to the Oman Sea from Iran. Hence, the amount of sediments decreases to the West. In the present deepwater areas, sediments older than Lower to Middle Miocene are subducted together with the oceanic crust, and the younger sediments above the décollement zone are thrusted and accreted [8].

Mud volcanoes have been reported both on- and off-shore along the Makran accretionary wedge (e.g., [24, 7]). Mud volcanoes onshore appear to be associated with E-W-trending fault zones [25] and sourced from the Upper Miocene Parkini mudstones [26]. Active mud volcanoes are present and pictured on offshore seismic profiles all along and near (within a few kilometers) the coast from West (e.g., [24]) to East, into Pakistan (e.g., [7]). The extruded very low-viscosity muds are cold, with near-ambient temperatures with few degrees variation (e.g., [24]). Traces of heavier hydrocarbons and isotopic compositions indicate gas generation from thermally mature source rocks. Fossils collected in erupted mud suggest a Middle Miocene over-pressured shale source [21].

Elevated marine terraces along the Makran coast indicate Quaternary surface uplift [27]. The uplift rate derived from Uranium series on shell sand and $14 \mathrm{C}$ chronology, which yields minimum ages, has been estimated from $0-0.2 \mathrm{~mm} / \mathrm{a}$ (western) to $0.5-2 \mathrm{~mm} / \mathrm{a}$ (eastern Makran) [27, 28]. Some studies have proposed that the $2 \mathrm{~m}$ of coastal uplift during the Holocene along the Iranian side is associated with a large ancient earthquake (e.g., [27, 2]). However, there is not enough evidence to indicate that large earthquakes have occurred in the last $1000 \mathrm{yr}$.

The Makran region is not characterized by a high seismic activity (Figure 1a). The eastern part of the subduction zone has been proposed as more seismically active than the western segment (e.g., 1765, 1851, and 1945 earthquakes), which is in good accordance with the occurrence of the $1945 \mathrm{Mw} 8.1$ earthquake [1]. According to thermal modelling, eastern Makran may have a wide seismogenic zone [29]. In contrast, only one major event was proposed for the western part, supposed to have 
occurred in 1483, with an inferred magnitude of $8.0[2,1]$. However, available oral records for this event are few and they are unable to certify the location along the subduction zone and the precise date. Musson [3] mentioned it was located in the Straight of Hormuz and probably not on the subduction megathrust itself.

Few studies have tried to estimate the interseismic coupling [5, 6]. Frohling and Szeliga [5] proposed a depth of locking of $38 \mathrm{~km}$ from the modelling of GPS velocities. Penney et al. [6] tried to retrieve coupling with better constrained slab dips. This study (with 17 stations among which 7 GPS stations along the coast distributed over $1000 \mathrm{~km}$ long) was only able to propose partial coupling along two profiles, one at $58^{\circ} \mathrm{E}$, the second at $60.5^{\circ} \mathrm{E}$. The authors found faster velocities along the eastern profile. They admitted that while precise geometry of locking could not be resolved with current data, the decrease of velocity towards the coast implied that some elastic energy must accumulate along the wedge.

\section{Data acquisition and processing}

The study area is located offshore, with seismic profiles gathered under auspices of NIOC (National Iranian Oil Company) in 2000 using conventional marine 2D seismic methodology. These are part of the PC2000 project covering both the Persian Gulf and the Oman Sea. The project comprises a seismic grid of $4 \mathrm{x} 4 \mathrm{~km}$ in the west and $8 \times 8 \mathrm{~km}$ in the central and eastern domains (Suppl. Mat. S1). The grid covers most of the seismic acquisition area, except in the deepest water areas towards the abyssal plain to the South.

Two phases of acquisition were conducted by seismic vessel Bin Hai 517, with basic acquisition parameters (recording length $8192 \mathrm{~ms}$, fold of coverage 120, cable length $6000 \mathrm{~m},[30])$. A last phase was recorded using seismic vessel Pejwak, with basic acquisition parameters (recording length $20480 \mathrm{~ms}$, fold of coverage (nominal fold) 90, cable length $7200 \mathrm{~m}$ ). Four lines were recorded in 20 seconds record length, although only two of them extend across the prism and deformation front. We also had access from NIOC to one onshore well located in Iran (black star, Figure 1). 
All steps of the conventional processing work flow such as demultipling, denoising, and prestack time migration (PSTM) have been applied to available data. The post-stack processing flow includes FX deconvolution and AGC (Automatic gain control). We here present three of these NS profiles orthogonal to the trench, located on the eastern, central and western part of the Iranian Makran. All seismic lines were interpreted in order to generate a structural map and to identify different structural provinces (Figure 1). In this study, the only source for depth conversion of seismic sections are seismic velocities. For proper integration of seismic velocities in a velocity model, we built a pseudo-3D velocity cube along each of our selected profiles to account for structural complexities in the velocity model processing (Figure Suppl. Mat. S1). The velocity model was obtained from the extrapolation of average velocities derived from seismic processing velocity data using Dix equation [31]. Depth conversion using interval velocities has also been tested. However, due to structural complexity, presence of shale diapirs and significant lateral variations of velocities within the wedge [11], this method did not provide results in good agreement with structures. Results obtained from average velocities for the three selected profiles are discussed in the following sections.

\section{Seismic data interpretation}

\subsection{Structural analysis}

The Oman Sea Basin is characterized by a complex structure (i.e., several plate boundaries, numerous thrusts and transfer faults [8, 23]) making the interpretation of regional and deep horizons difficult. While several deep horizons can be interpreted within localized basins or sub-areas, their correlation into the next sub-basin is uncertain since they may be separated by a tectonic high, mud volcanoes, transfer faults and/or thrusts extending nearly to the seabed. Seismic horizons in the Oman Sea Basin were thus defined herein by screening all seismic lines and picking out potential correlations based on particularly strong reflectors, clear unconformities or other characteristics as the cross-cutting BSR horizon and the décollement. Profiles 


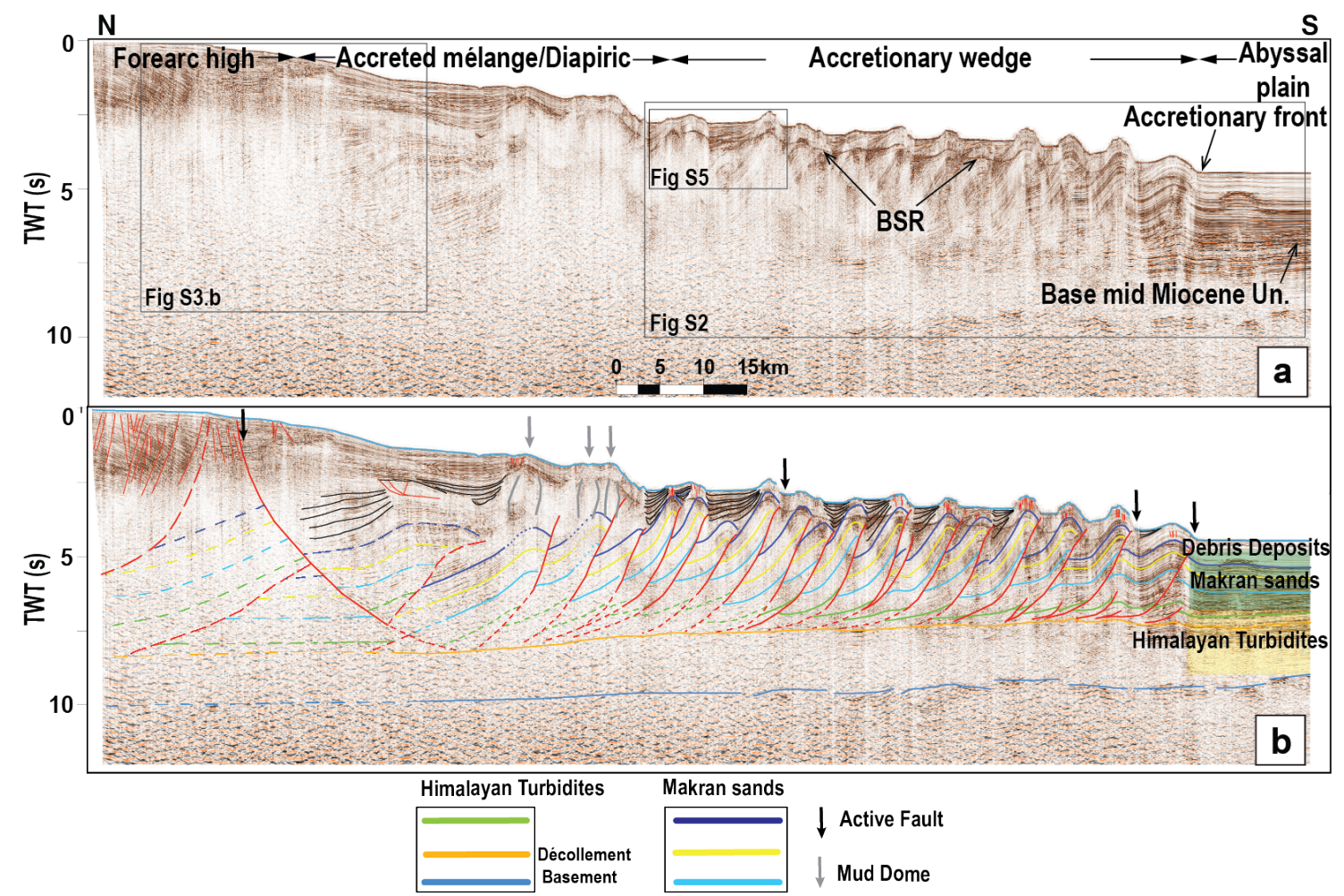

Figure 2: a. 2D offshore Eastern seismic profile across the Makran subduction zone from PC2000 in time (see Fig. 1 for location). b. Interpreted profile showing the link between the extensional province on the shelf and the contraction at the toe with thrust systems, as well as the main structural domains.

were further scrutinized whenever data quality allowed.
The wide continental wedge can be divided into three parts (Figures $1 ; 2 ; 4 ; 5)$ : (1) the accretionary wedge, (2) the accreted mélange and (3) the forearc high. In western Makran, the accretionary wedge consists of a series of fold/thrust ridges separated by small piggy-back basins. A Bottom Simulating Reflector is caused by small amounts of free gas trapped below the sealing gas hydrate layer that crosscuts seismic reflectors. The horizon runs parallel to the seabed (Figures 2; 4) and is observed on nearly all seismic lines, for water depths greater than $1300 \mathrm{~m}$. The accreted mélange is a complex structure, where nearly no primary bedding is preserved and no major structure is observed [32]. In general, the accreted mélange has a diapiric character along the entire accretionary complex. Major seaward normal faults that seem to root down to the décollement and shallower ones are observed along the coast and the shelf on the eastern and western domains [33]. By cross- 
cutting lithologies, their age is estimated to be younger than Late Miocene [34].

One onshore well is located on the Iranian side but does not intersect the seismic profiles (black star, figure 1). However, the well shows that a large thickness of young sediments is deposited close to shoreline, with a $4164 \mathrm{~m}$ drilled section and a total depth in Upper Miocene sediments. This well consists of silty shales and shaly sands, interbedded with thin sandstone intervals. Most of the published general stratigraphy is available from onshore Pakistan $[25,33,35]$. As mentioned above, the $7.5 \mathrm{~km}$ thick sediments [11] consist of about $4 \mathrm{~km}$ of Himalayan Turbidites which have been interpreted as turbidites deposits and also as hemipelagic muds [33], and are equivalent to the Hoshab and Panjgur formations of onshore Makran. The Late Oligocene - Early Miocene Hoshab formation is composed of calcareous mudstones with intercalation of sandstones [35] and the Middle Miocene Panjgur formation [36] consists of thick bedded sandstone and conglomerates with thin bedded shale [33]. On top of the Himalayan Turbidites lies a $3 \mathrm{~km}$ unit of Makran Sands composed of sandstone and siltstone of possible age Late Miocene to Pliocene [23]. This unit is alike the Parkini and Talar formations of onshore Makran [26]. The Quaternary hemipelagic sediments include a mixture of shelf and slope turbiditic sands, turbiditic silts or aeolian dust and, fluvial muds [37] that are equivalent to the Chatti mudstone Ormara and Jivani formations [23] (Figure 2b).

\subsection{Eastern profile}

The Eastern profile, located south of Chabahar, is the longest available seismic reflection profile, running over $140 \mathrm{~km}$ from the coast to the trench. The cross-section was first drawn in time (Figure 2) and then converted to depth (Figure 3). Water depth ranges from $0 \mathrm{~m}$ at the coastline to over $3300 \mathrm{~m}$ within the study area. There are $6.5-7 \mathrm{~km}$ of sediments deposited on the abyssal plain, with a total thickness of the sedimentary pile above the main basal décollement ranging between 7 and 11 $\mathrm{km}$.

The proposed seismic interpretation builds on Grando and McClay [23]. The 


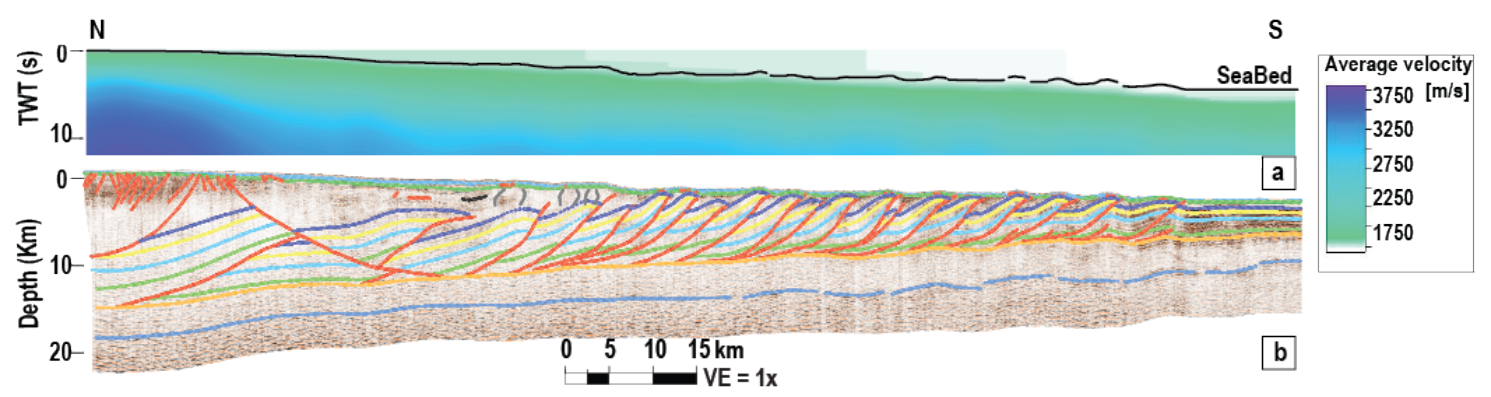

Figure 3: a. Smoothed average velocity profile for the Eastern profile obtained from the Seismic velocity data b. Depth section and interpretation $(\mathrm{VE}=1)$.

$78 \mathrm{~km}$ long imbricated zone is composed of seventeen thrust sheets, with increasing spacing between the thrusts and decreasing dips towards the front [23] (Figures 2, 3 and Suppl. Mat. S2). The mud diapir is located between a large seaward normal fault and the imbricated zone. Due to the weak resolution of the seismic image in this area, its source layer is debatable. According to our interpretation and previous studies $[25,24,7,21]$, it is most likely confined within a shallower and local décollement level. Due to the presence of shale and mud, the quality of the seismic data near the coast of the selected profile is quite poor. However, the comparison with surrounding lines allows us to root the seaward normal fault to the décollement (Figure Suppl. Mat. S3). The formation of these normal faults is probably related to the presence of deep duplexes $[23,36]$ visible on surrounding lines (Figure Suppl. Mat. S4), and to gravitational collapse [38]. From tilting of recent sediments, fanning, wedge shaped growth packages of sediment and fault tip at surface, we identify three main locations of active faulting: (1) the large seaward normal fault, (2) some thrust faults ahead of the diapiric zone, and (3) the frontal thrusts.

To validate our structural interpretation, we restored the cross-section according to Dahlstrom [39]'s method, based on the hypothesis that the length of beds remains constant during deformation in concentric folds. Cross-balancing was performed for the whole profile, excepted for the mud area where the volume conservation hypothesis does not hold (Figure Suppl. Mat. S6). The measured shortening from the deformation front to the northern tip of the section is of $65 \mathrm{~km} \pm 10 \mathrm{~km}(32 \pm$ 


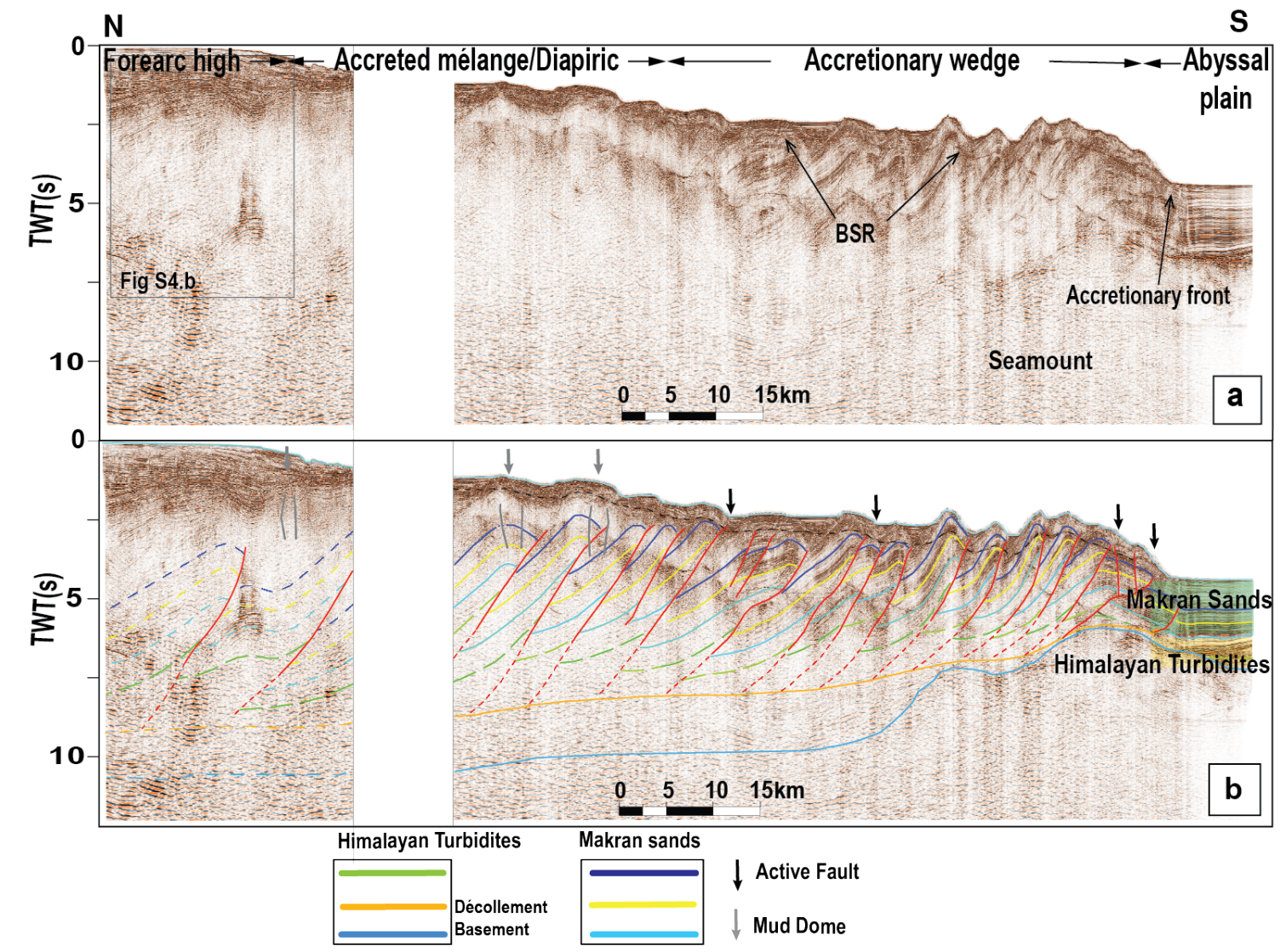

\subsection{Central profile}

The total length of this cross-section is $122 \mathrm{~km}$, excluding a $10 \mathrm{~km}$ gap located in the diapiric zone (Figure 4). Water depth ranges from $0 \mathrm{~m}$ at the coastline to over $3100 \mathrm{~m}$ above the abyssal plain. A seamount of possible volcanic origin is visible at the front. The seamount is probably currently being subducted underneath the outermost part of the imbricated zone, generating strong uplift of the frontal folds. Thrusts on top of it are thus steeper in comparison with the Eastern profile. Only $4 \mathrm{~km}$ of sediments is deposited on top of the seamount.

Figure 4: a. Central seismic profile of the study area (location on Figure 1). b. Interpreted profile. A seamount is visible at the accretionary front and has created antiformal stack structures. 
The frontal thrusts and some thrusts located at the back of the imbricated zone are identified as active.

Balancing of the cross-section suggests a total shortening, from the deformation front to the diapiric zone ( $85 \mathrm{~km}$ of folded thrusts), of $50 \pm 5 \mathrm{~km}$ (37 \pm 2 percent of the initial length), i.e., 5 percent longer than in eastern section. The difference is most probably due to the presence of the seamount indentation causing a reentrant.

The seamount (Figure Suppl. Mat. S7) increases the basal slope and creates an imbricate stack leading to an increased shortening of the shallow portion of the wedge.

\subsection{Western profile}

The $97 \mathrm{~km}$ long Western profile does not reach the trench (Figure 5). Water depth varies from $0 \mathrm{~m}$ to $1700 \mathrm{~m}$ to the southern end of the line. The profile is here again characterized by a large seaward normal fault that seem to root down to the décollement (Figure S3), a shale diapir zone, and the imbricated thrust zone. As along the eastern profile, we identify three main active fault zones: the seaward normal fault, thrusts ahead of the diapiric zone, and the frontal thrusts of the accretionary prism.

Seismic profiles allow proposing a structural map of the Iranian Oman sea with the following first-order characteristics: a long imbricated thrust zone takes place at the front of the wedge; a diapiric zone of shallow origin lies in between the imbricated zone and the shore; some thrusts ahead of the diapiric zone are identified as active. The eastern and western areas are characterized by active listric normal faults located along the shorelines and rooting down to the décollement, whereas the central domain shows no evidence of large normal faulting, a larger diapiric zone, and is affected by a seamount entering into subduction. We thus propose to separate western Makran in three different structural domains: Eastern, Central and Western. 


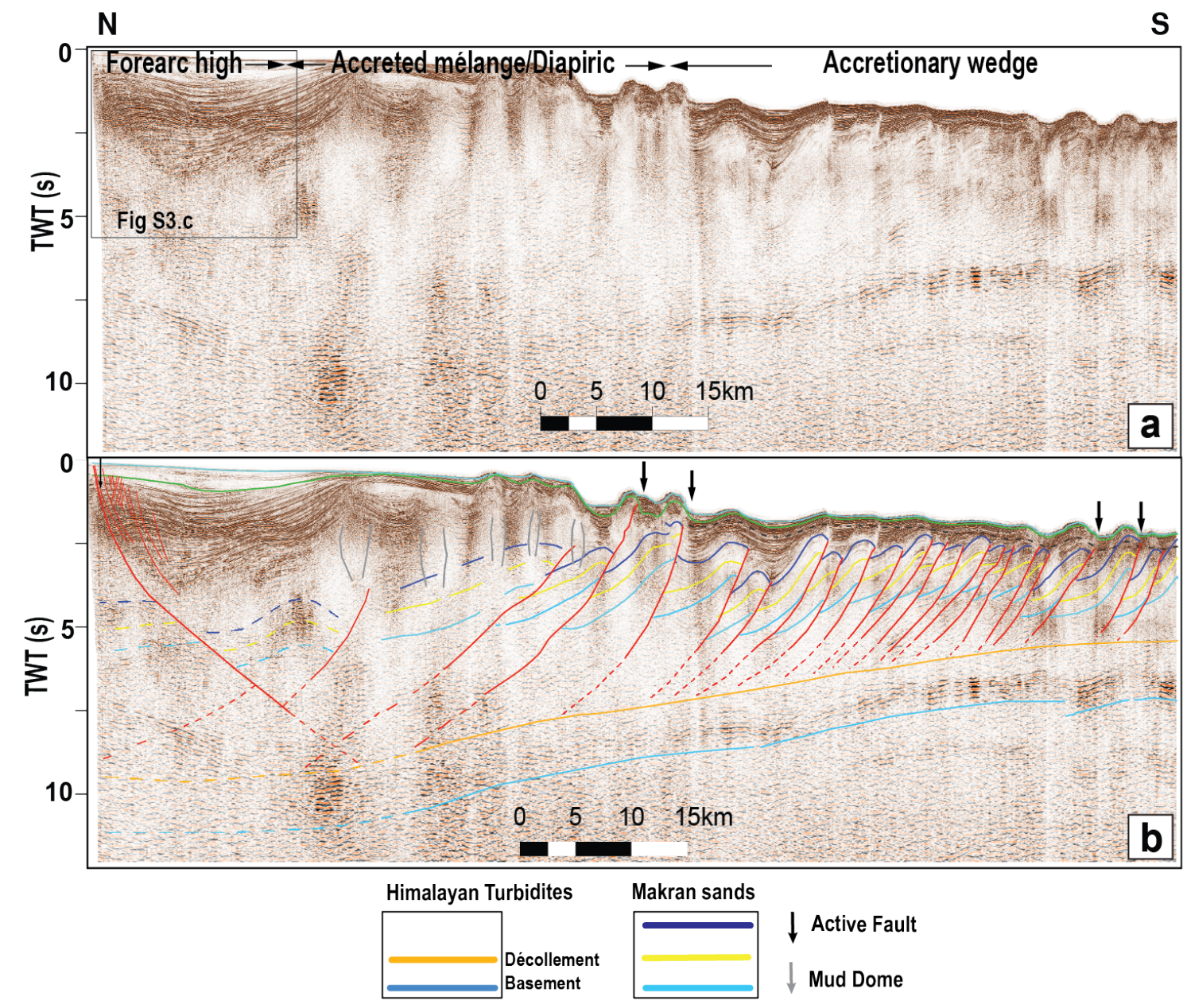

Figure 5: a. Regional N-S Western profile of the offshore Makran accretionary prism (location on Figure 1). b. Interpreted profile.

\section{Mechanical modelling}

In order to discuss the seismogenic potential of the megathrust, we propose to determine its frictional properties. Due to the high sedimentation rate, a high pore fluid pressure is expected in the sedimentary cover and needs to be estimated before running mechanical models. We thus conducted a two stage-analysis. First, we applied the critical taper theory over the entire area to confirm the location of active deformation, to constrain the pore fluid pressure of the wedge, and to provide a first estimate of the megathrust effective friction [40, 18]. Second, we applied the limit analysis approach, to get the along dip variation of the megathrust effective friction along the Eastern and Central profiles. Due to the seamount subduction, the décollement of the Central profile is quite rough, results are thus partial and 
presented in supplementary material (Suppl. Mat. S7). Since the Western profile does not reach the trench, the analysis could unfortunately not be carried out on this profile.

\subsection{Critical taper map}

We first explore the mechanical state and the frictional properties of western Makran with the help of the Critical Taper Theory (CTT) [41, 18]. This theory allows us to relate the general shape of a wedge formed by its topographic slope and the slab dip with the frictional properties of the wedge and megathrust. The relation forms an envelope separating three different mechanical states (Figure 6a): (1) a critical state, if the wedge follows the envelope. In that case, the megathrust and the wedge are on the verge of failure, implying active faulting within the wedge; (2) a stable state, if the wedge is inside the envelope. At stable state, the whole wedge slides along its megathrust without producing any internal permanent deformation; (3) unstable state, if the wedge is outside the envelope and cannot slide along its megathrust. Frictional properties can only be estimated if the wedge is at critical state and follows a critical envelop, which implies a co-variation of the topographic slope and slab dip.

Following the method of Cubas et al. [18], we used ETOPO 1 for the bathymetric and topographic slope. The slab morphology could not be calculated from the full seismic data set because of partial coverage. We thus used slab 2.0 [42], after checking its consistency with the Eastern profile. We plotted cross-sections perpendicular to the trench and constructed swath profiles to get the co-variation of the topographic slope and slab dip with standard deviations for the inversion procedure (Figure 6b). Along these profiles, we looked for segments at critical state, i.e., parallel to a critical envelop (Figure 6a, b). For each of these segments, we retrieved by inversion the friction of the wedge, the pore pressure ratio of the wedge and the effective friction coefficient of the megathrust (Figure 6c, d). Effective friction coefficients are defined as $\mu^{e f f}=\tan \phi^{\text {eff }}=(1-\lambda) \tan \phi$, where $\lambda$ is the Hubbert-Rubbey fluid pressure ratio [40]. 

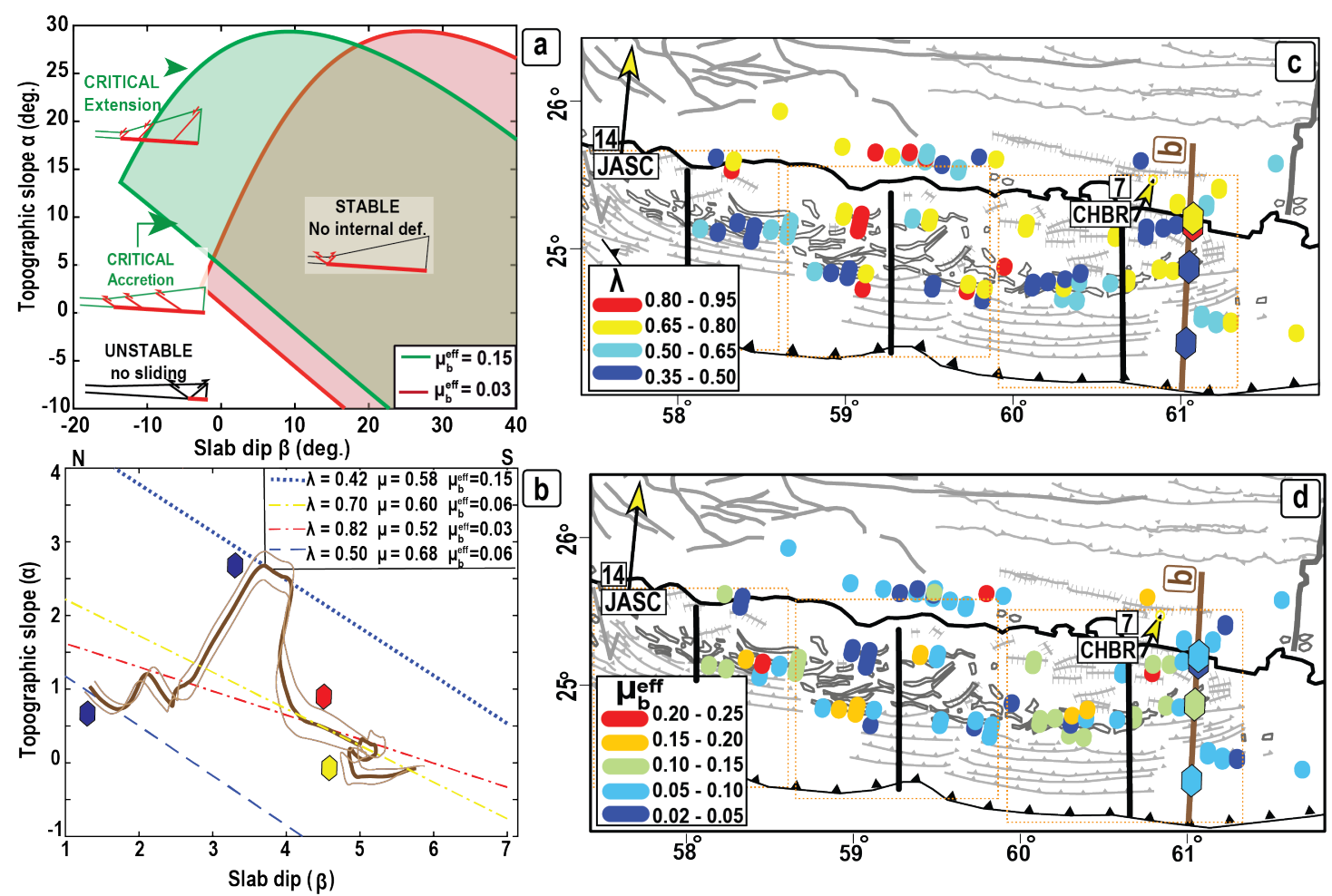

Figure 6: a. Critical envelopes and mechanical states for effective megathrust frictions of 0.15 and 0.03. b. Example of the $\alpha / \beta$ co-variation for a swath profile located along the eastern part of Makran (see location on $\mathrm{c}$ and $\mathrm{d}$ ). Bold brown line: $\alpha / \beta$ values of the swath, cream lines: $\alpha / \beta$ mean \pm standard deviation. The diamond symbols denote the 4 segments identified at critical state (i.e., parallel to a critical envelope as described in a.). For each of these identified segments, the frictional properties are retrieved by inversion and given in the legend. The dashed color lines represent the lower branch of the critical envelop for each of the best fit set of parameters. Their location and properties are reported on panel $\mathrm{c}$ and $\mathrm{d}$ with diamonds. c. Pore pressure ratio of the wedge for segments at critical state and $\mathbf{d}$. Effective friction coefficient of the megathrust for segments at critical state. The diamond symbols denote the four segments of $b$. The three structural domains are identified by dashed-orange boxes.

The slab morphology given by slab 2.0 is partly made of straight segments with

kinks complicating the application of the method. However, although the errors on the slab geometry can affect the deduced effective frictions, the critical state usually remains valid for a large range of slab dip values [18].

Figure $6 \mathrm{c}, \mathrm{d}$ shows patches of the prism at critical state, in particular in front of the mud diapirs, near the active out-of sequence thrusts identified on the seismic lines. Critical patches are also found in the Central domain where mud diapirs are present. Some critical patches lie along the coast consistent with the presence of deep duplexes. Active faulting identified on the seismic lines is thus supported by the CTT analysis. On the eastern and western borders, frontal and coastal critical patches get closer. Effective friction of the megathrust range between 0.017 and 0.23 
and the pore fluid pressure in the wedge varies from hydrostatic to almost lithostatic.

Along the Eastern profile, we found a $\mu^{e f f}$ of 0.1 in front of the mud diapirs, and an internal pore fluid pressure ratio of $\lambda=0.6$.

Since this theory only provides effective friction of critical areas and since this coefficient might be biased by the slab geometry, we then look for the frictional properties allowing to reproduce the actual deformation with a complementary mechanical approach.

\subsection{Spatial variation of frictional properties from mechanical modelling}

To do so, we rely on the limit analysis method [43, 44], which is based on the principle of virtual powers and the theorem of maximum rock strength [45]. In this study, the Coulomb criterion is used for maximum rock strength. The principle of virtual power consists in studying the collapse mechanisms, in our study faults, by applying a virtual displacement over the structure. The method investigates all possible distribution of faults as a function of the mechanical properties and selects the optimal one minimizing the tectonic pushing force. Since deformation is obtained from the chosen mechanical properties (such as frictions and cohesions), if deformation is known, the frictional parameters can be retrieved by inversion. This approach has already been applied to constrain megathrust friction [18, 19, 46].

For this study, we used the Optum-G2 software (Optum G2, 2013). To model the Eastern profile, we used the geometry obtained from the depth conversion (Figure 3). Typical value of cohesions and internal frictions were chosen to reproduce the stratigraphy, composed of the Makran Sands formed by interbeds with different percentages of sandstone and siltstone, the Himalayan turbidites, a shale level for the décollement, and a basaltic basement (Figure 7a) [47]. Since the Optum software does not deal with over-pressure, we used effective friction coefficients, considering a wedge pore fluid ratio of $\lambda=0.6$ as inferred from the CTT.

To retrieve the effective friction coefficient along the megathrust, we searched for the range of values reproducing the observed deformation, i.e., the seaward normal fault rooting on the megathrust, the first thrusts located ahead of the mud diapirs 

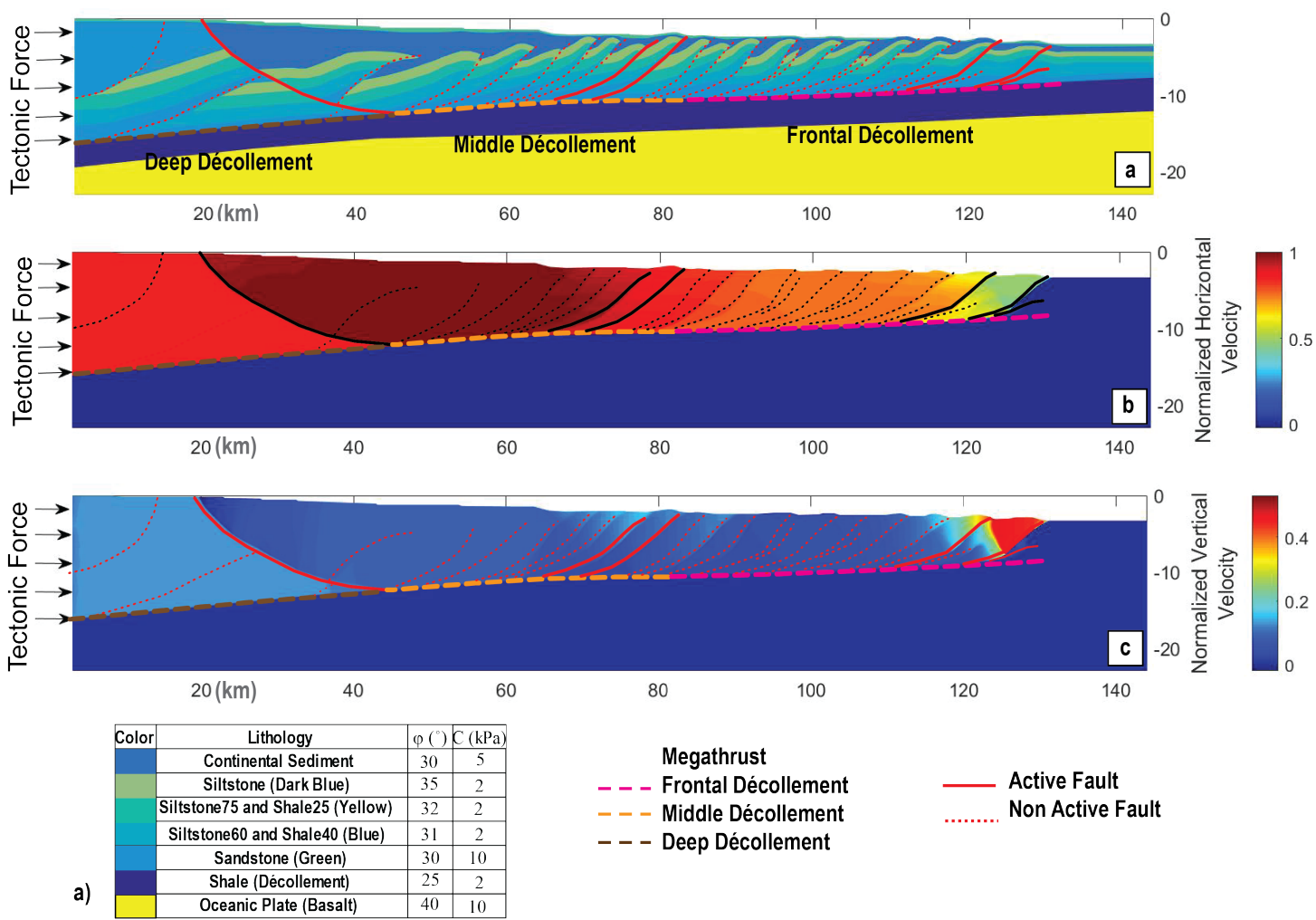

Figure 7: a Model set-up with three distinct décollement segments, to seek for the frictional properties reproducing the observed active deformation. The deep décollement has a dip of $\beta_{\text {deep }}=5^{\circ}$, and the pore fluid pressure ratio in the wedge is set to $\lambda=0.6$ as deduced from the CTT. $\mathbf{b}$ Normalized virtual vertical and $\mathbf{c}$ horizontal velocities showing the relative motion between the blocks, obtained for $\lambda=0.6, \phi_{\text {deep }}^{\text {eff }}=3^{\circ}, \phi_{\text {middle }}^{\text {eff }}=0.6^{\circ}$ and $\phi_{\text {front }}^{\text {eff }}=1^{\circ}\left(\mu_{\text {deep }}^{\text {eff }}=0.052, \mu_{\text {middle }}^{\text {eff }}=0.01\right.$ and $\left.\mu_{\text {front }}^{e f f}=0.017\right)$.

and the thrusts at the toe.

To activate the entire megathrust and fit the observed deformation, three segments are needed, hereafter named frontal, middle and deep décollement (Figure 7). Although deformation might be sequential at very short-time scale, the displacement of the middle and frontal segments is generated by the displacement of the deepest segment. Hence, the deformation of one segment can not be modelled independently of the others. All possible effective frictions along these three segments were investigated, which led to seven different kinematics described in figure 8a. Kinematics $\mathbf{g}$ captures the observed active faults, and we now discuss the range of frictions obtained.

First of all, simulations indicate that a very low effective friction coefficient is required to activate the entire megathrust (Figure 8b). However, to activate the 


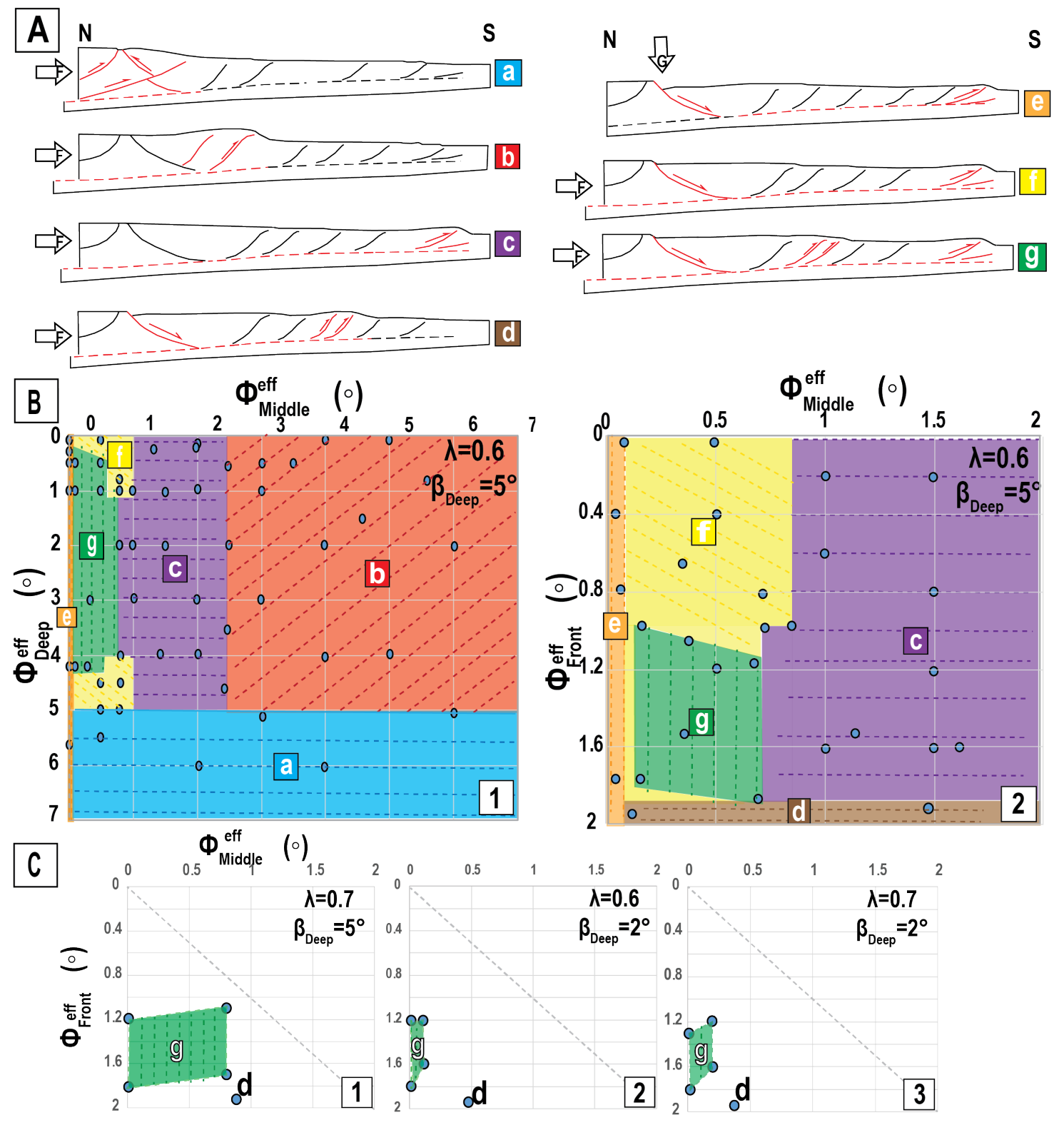

Figure 8: A. Kinematics obtained for the range of effective frictions along the décollement provided in figure $\mathbf{B}$ and $\mathbf{C}$. a-f are failure models, $\mathbf{g}$ is the kinematics we seek to reproduce (a: Normal fault acts as reverse and décollement not active, b: Normal fault and décollement non-active, c: Normal fault and out-of-sequence thrust faults non-active, d: Décollement partially active, e: Gravitational normal fault, f: Normal faulting but non-active out-of-sequence thrust faults, g: Normal faulting, out-of-sequence thrust faults and full décollement active). B.1 Exploration of kinematics for varying effective friction coefficients along the middle and deep décollement. Circles correspond to simulations, colored areas to kinematical domains, with kinematics $\mathbf{g}$ in green. B.2 Exploration of kinematics for varying effective friction coefficients along the frontal and middle décollement. C. 1-3. Frictions along the frontal and middle décollement reproducing kinematics g. Two different pore pressure ratios $(\lambda=0.6$ and 0.7$)$ and two different décollement dips $\left(\beta=2^{\circ}\right.$ and $5^{\circ}$ ) are investigated.

normal fault, a decrease of friction from the deep segment to the middle one is necessary (Figures 8b, 7). To activate the out-of-sequence thrusts and propagate the deformation to the front, an increase of friction along the frontal segment is 
necessary. As a consequence, the effective friction of the middle décollement has to be lower than the deep and frontal segments. Only a limited range of effective frictions can reproduce kinematics $\mathbf{g}$ (Figure $8 \mathrm{a}$ and $\mathrm{b}$, Table 1). For $\lambda=0.6$, along the middle décollement, the effective friction can vary from $\mu_{\text {Middle }}^{e f f}=0.003$ to 0.012 , with higher effective friction coefficients along the deeper and shallow segments as given in Table 1.

\begin{tabular}{|l|lll|}
\hline & Deep & Middle (lower bound) & Front \\
\hline$\phi^{\text {eff }}$ & $0.8-3.7^{\circ}$ & $0.02^{o}$ & $1-1.8^{o}$ \\
$\mu^{\text {eff }}$ & $0.01-0.06$ & 0.003 & $0.017-0.031$ \\
\hline & Deep & Middle (upper bound) & Front \\
\hline$\phi^{\text {eff }}$ & $1-3.7^{\circ}$ & $0.7^{o}$ & $1.2-1.9^{o}$ \\
$\mu^{\text {eff }}$ & $0.017-0.065$ & 0.012 & $0.02-0.033$ \\
\hline
\end{tabular}

Table 1: Frictional properties along the megathrust reproducing kinematics $\mathbf{g}$ with $\lambda=0.6$.

To strengthen our analysis, we also tested different pore fluid pressure ratios and a lower slab dip $\left(\lambda=0.7, \beta=2^{\circ}\right.$, Figure $8 \mathrm{C}$ ) (a larger slab dip is inconsistent according to cross-balanced reconstruction). Again, the effective friction of the middle décollement needs to be lower than the deep and frontal segments.

This result is consistent with the critical taper theory. The middle segment, with a normal fault at the back and thrusts ahead should be on the verge of extensional critical limit, whereas the frontal segment with only thrust faults is at or close to the compressional critical state. For similar $\alpha$ and $\beta$, this change of state can only be achieved with lower effective friction along the middle segment.

The same procedure was applied to the Central profile (Figure 4). We again used the depth converted geometry (Figure Suppl. Mat. S7), and set all cohesions and frictions to standard values corresponding to the lithology (Figure Suppl. Mat. S8). We applied a pore fluid ratio $\lambda=0.8$ as deduced from the CTT (Figure $6 \mathbf{c})$. Due to the presence of the seamount and the roughness of the frontal portion of the décollement, an extremely low effective friction is needed along the frontal décollement to propagate the deformation to the front $\left(\phi_{\text {front }}^{e f f}=0.4^{o}-0.6^{o}, \mu_{\text {front }}^{e f f}\right.$ $=0.007-0.01)$. However, the behavior of this frontal segment is probably closer to distributed deformation than to localised deformation along the megathrust [48], 
and might not be captured with this approach. For the middle segment, we again found very low effective friction coefficients, ranging from $0.1^{\circ}$ to $2^{o}\left(\mu_{\text {middle }}^{\text {eff }}=0.002-\right.$ $0.034)$.

\section{Discussion - Conclusion}

According to the structural analysis, western Makran can be separated in three different structural domains. The eastern one is characterized by active listric normal faults located along the shorelines and rooting down to the décollement, limited extent of mud volcanoes, out-of-sequence thrusts ahead, and an imbricated zone. The central domain shows no evidence of large normal faulting, presents a larger diapiric zone, and the imbricated zone is affected by a seamount entering into subduction at the front. The western domain is very similar to the eastern one. Three zones of active deformation have been identified, supported by the CTT analysis: listric normal faults on the shelf, several thrust faults ahead of the diapiric zone, and the frontal thrusts.

To reproduce the deformation of the Eastern profile, an extremely low effective friction is required between the seaward normal fault and the back of the imbricated thrust zone. A decrease of effective friction is needed to activate the normal fault, whereas an increase is required to propagate deformation to the trench. Along the Central profile, an extremely low friction is also requiblue along the middle segment of the décollement. Although the method could not be applied to the partial Western profile, the fact that deformation resembles that of the Eastern profile suggests similar transitions of mechanical properties.

The very low and extremely low effective frictions are most probably explained by near lithostatic pore fluid pressures. Low effective frictions have also been proposed along the Pakistani side of Makran [49, 8], hence high pore pressures are probably a common trend over the whole subduction zone due to the extremely high sedimentation rate. However, these lithostatic pore fluid pressures can either be a long-term or transient feature. Indeed, the inferred effective frictions are the 
frictions necessary to reproduce the deformation. As a consequence, if deformation is aseismic, these frictions would represent the effective friction at slow slip rate and the pore fluid pressure would be a long-term feature. If deformation is acquired during earthquakes or very shortly after, then the retrieved effective megathrust friction would correspond to the dynamic friction. In that case, a already high pore fluid pressure related to the sedimentation rate could reach even larger values due to additional dehydration processes and thermal-pressurization acting during the propagation of earthquakes $[50,51]$.

Considering that GPS data show some accumulation of elastic strain $[4,5,6]$ and that dynamic effective friction coefficients are lower than friction coefficients of slow slip rate e.g., [15], this extremely low friction may reflect dynamic weakening and the presence of a seismic asperity.

Splay faults branch upward from the plate boundary of subduction margins, and are common in most subduction zones (e.g., [52, 53]). Their high tsunamigenic potential due to their rupture during mega-earthquakes has been discussed in many mega-tsunami events. A particular relationship between normal and splay faults with seismic asperities has been observed during some recent major events. For instance, during the $2010 \mathrm{Mw} 8.7$ Maule earthquake, a backthrust splay fault located up-dip of the high slip patch has been activated leading to a significant uplift of the Santa Maria island [53]. Two weeks after the main shock, two normal-faulting aftershocks occurred along the down-dip limit of the high slip patch [54]. A seaward normal fault rooting down to the megathrust was highlighted by crustal seismicity. During the 2011 Mw 9.0 Tohoku-Oki earthquake, a landward normal fault was activated at the transition between the high and the moderate slip patches [55]. Moreover, the Tohoku-Oki earthquake was followed by a shallow normal-faulting earthquake sequence located along the Pacific coast, in a compressional domain [56]. An active crustal-scale normal fault system that dips landward and resembles the one involved in the Tohoku-oki earthquake as also been identified along the Shumagin Gap in Alaska, and has been associated to a high tsunamigenic risk [57]. The 
activation of these normal faults has been related to variations of effective friction along the megathrust from seismogenic to aseismic portions of the megathrust $[18$, 19] and to the release of gravitational potential energy [58]. According to McKenzie and Jackson [58], earthquakes would not only release elastic energy stored during the interseismic period, but also gravitational potential energy due to the sudden and strong decrease of the megathrust friction.

These splay fault examples thus support our interpretation: the extremely low friction between the normal fault and the out-of sequence thrusts of the imbricated zone would thus correspond to dynamic frictions reached during earthquake propagation, leading to the release of gravitational potential energy and the activation of the listric normal faults, and possibly of the out-of-sequence thrusts.

Therefore, the slip deficit, the deformation and frictions along the megathrust are all pointing to the presence of at least two seismic asperities located in between the listric normal faults and the out-of-sequence thrusts, one along the eastern domain and a second along the western domain (Figure 9).

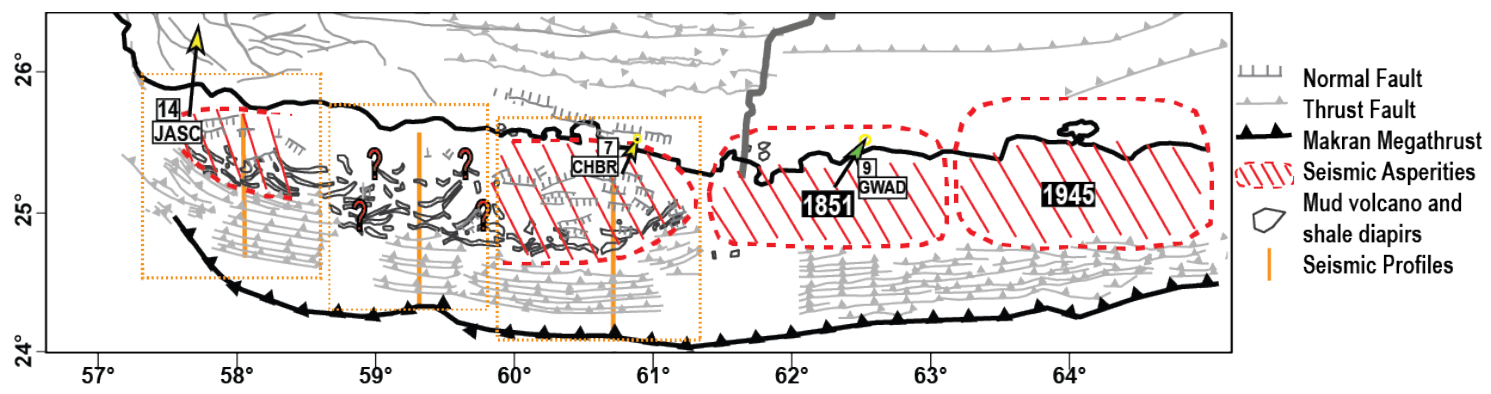

Figure 9: Areas of high seismogenic potential along the Makran subduction zone, according to our structural and mechanical analysis and past seismic ruptures from [4]. The three structural domains are identified by dotted-orange boxes

The behavior of the Central domain is more difficult to predict. The same low effective friction coefficient is consistent with a seismic asperity. However, frictional transitions are uncertain due to the lack of normal faults and more complex deformation at the front induced by the seamount. This absence can be interpreted in two ways: either the lack of normal faults is due to a change of slope, potentially induced by the seamount subduction at the front, or to the absence of a seismic 
asperity. GPS stations along the central domain are thus mandatory for a better assessment of seismic hazard in this region.

Several studies have also proposed that some continental wedge structures could attest to the propagation of earthquakes to the surface as landward vergence thrusts [20, 59]. Along western Makran, however, the prism is made of regular seaward thrusts that do not show any evidence for such propagation. Tsunamigenic hazard is thus probably limited to the identified normal faults and the out-of-sequence thrusts [58].

Similar features along Pakistani Makran support our interpretation. Eastern Makran is also characterized by a $70 \mathrm{~km}$ long imbricated zone made of regular seaward thrusts $[11,49,8]$, followed by a flat mid-slope terrace [49]. The frontal wedge is characterized by a low taper suggesting some overpressure [49, 8]. The three last major earthquakes, including the 1945 Mw 8.1, that struck Eastern Makran have a similar along-dip extent as our proposed asperities: from the coastal region to the rear of the imbricated zone at the change of slope. [1] (Figure 9). Based on 2D thermal modelling and assuming uniform coupling between the $150^{\circ}$ and $350^{\circ}$ isotherms depths, Smith et al. [29] have proposed a potentially wide seismogenic zone extending from the trench up to $\sim 350 \mathrm{~km}(60 \mathrm{~km}$ depth). However, this along-dip extent is not supported by InSAR observations, suggesting a high to moderate coupling down to $20 \mathrm{~km}$ depth (180 km from the trench), coincident with the down-dip limit of the 1945 earthquake, followed by a strong decrease with depth. The authors also detected lateral variations of coupling revealing a possible along-strike segmentation [4].

Therefore, along Western Makran where no large earthquake has been historically reported despite the high convergence rate, a major event has to be expected. We suggest that the magnitude of this event will depend on the mechanical behavior of the Central domain, and the ability of the earthquake to propagate from the eastern to the western asperity or to eastern Makran. 
Acknowledgements The authors thank National Iranian Oil Company (NIOC) exploration for providing data and permission to publish. We thank Lisa McNeill and an anonymous reviewer for their constructive comments.

\section{Appendix}

See supplementary material for supporting figures.

\section{References}

\section{References}

[1] D. E. Byrne, L. R. Sykes, D. M. Davis, Great thrust earthquakes and aseismic slip along the plate boundary of the makran subduction zone, Journal of Geophysical Research: Solid Earth 97 (1992) 449-478.

[2] N. Ambraseys, C. Melville, A history of persian earthquakes cambridge university press, 1982 .

[3] R. Musson, Subduction in the western makran: the historian's contribution, Journal of the Geological Society 166 (2009) 387-391.

[4] Y. Lin, R. Jolivet, M. Simons, P. Agram, H. R. Martens, Z. Li, S. Lodi, High interseismic coupling in the eastern makran (pakistan) subduction zone, Earth and Planetary Science Letters 420 (2015) 116-126.

[5] E. Frohling, W. Szeliga, Gps constraints on interplate locking within the makran subduction zone, Geophysical Supplements to the Monthly Notices of the Royal Astronomical Society 205 (2016) 67-76.

[6] C. Penney, F. Tavakoli, A. Saadat, H. R. Nankali, M. Sedighi, F. Khorrami, F. Sobouti, Z. Rafi, A. Copley, J. Jackson, et al., Megathrust and accretionary wedge properties and behaviour in the makran subduction zone, Geophysical Journal International 209 (2017) 1800-1830. 
[7] A. M. Kassi, A. K. Kasi, J. McManus, A. S. Khan, Lithostratigraphy, petrology and sedimentary facies of the late cretaceous-palaeocene ispikan group, southwestern makran, pakistan., Journal of Himalayan Earth Science 46 (2013).

[8] G. Smith, L. McNeill, T. J. Henstock, J. Bull, The structure and fault activity of the makran accretionary prism, Journal of Geophysical Research: Solid Earth 117 (2012).

[9] F. Masson, M. Anvari, Y. Djamour, A. Walpersdorf, F. Tavakoli, M. Daignières, H. Nankali, S. Van Gorp, Large-scale velocity field and strain tensor in iran inferred from gps measurements: new insight for the present-day deformation pattern within ne iran, Geophysical Journal International 170 (2007) 436-440.

[10] C. DeMets, R. G. Gordon, D. F. Argus, Geologically current plate motions, Geophysical Journal International 181 (2010) 1-80.

[11] C. Kopp, J. Fruehn, E. Flueh, C. Reichert, N. Kukowski, J. Bialas, D. Klaeschen, Structure of the makran subduction zone from wide-angle and reflection seismic data, Tectonophysics 329 (2000) 171-191.

[12] D. Oleskevich, R. Hyndman, K. Wang, The updip and downdip limits to great subduction earthquakes: Thermal and structural models of cascadia, south alaska, sw japan, and chile, Journal of Geophysical Research: Solid Earth 104 (1999) 14965-14991.

[13] C. H. Scholz, Earthquakes and friction laws, Nature 391 (1998) 37.

[14] J. P. Loveless, B. J. Meade, Spatial correlation of interseismic coupling and coseismic rupture extent of the $2011 \mathrm{mw}=9.0$ tohoku-oki earthquake, Geophysical Research Letters 38 (2011).

[15] X. Gao, K. Wang, Strength of stick-slip and creeping subduction megathrusts from heat flow observations, Science 345 (2014) 1038-1041. 
[16] G. Di Toro, R. Han, T. Hirose, N. De Paola, S. Nielsen, K. Mizoguchi, F. Ferri, M. Cocco, T. Shimamoto, Fault lubrication during earthquakes, Nature 471 (2011) 494 .

[17] P. Fulton, E. E. Brodsky, Y. Kano, J. Mori, F. Chester, T. Ishikawa, R. Harris, W. Lin, N. Eguchi, S. Toczko, et al., Low coseismic friction on the tohoku-oki fault determined from temperature measurements, Science 342 (2013) 12141217.

[18] N. Cubas, J.-P. Avouac, P. Souloumiac, Y. Leroy, Megathrust friction determined from mechanical analysis of the forearc in the maule earthquake area, Earth and Planetary Science Letters 381 (2013) 92-103.

[19] N. Cubas, J.-P. Avouac, Y. M. Leroy, A. Pons, Low friction along the high slip patch of the $2011 \mathrm{mw} 9.0$ tohoku-oki earthquake required from the wedge structure and extensional splay faults, Geophysical Research Letters 40 (2013) $4231-4237$.

[20] N. Cubas, P. Souloumiac, S. C. Singh, Relationship link between landward vergence in accretionary prisms and tsunami generation, Geology 44 (2016) $787-790$.

[21] J.-P. Burg, Geology of the onshore makran accretionary wedge: Synthesis and tectonic interpretation, Earth-Science Reviews 185 (2018) 1210-1231.

[22] U. Von Rad, U. Berner, G. Delisle, H. Doose-Rolinski, N. Fechner, P. Linke, A. LŘckge, H. Roeser, R. Schmaljohann, M. Wiedicke, et al., Gas and fluid venting at the makran accretionary wedge off pakistan, Geo-Marine Letters 20 (2000) 10-19.

[23] G. Grando, K. McClay, Morphotectonics domains and structural styles in the makran accretionary prism, offshore iran, Sedimentary Geology 196 (2007) $157-179$. 
[24] G. Delisle, U. Von Rad, H. Andruleit, C. Von Daniels, A. Tabrez, A. Inam, Active mud volcanoes on-and offshore eastern makran, pakistan, International Journal of Earth Sciences 91 (2002) 93-110.

[25] S. S. Ahmed, Tertiary geology of part of south makran, baluchistan, west pakistan, AAPG Bulletin 53 (1969) 1480-1499.

[26] H. Schlüter, A. Prexl, C. Gaedicke, H. Roeser, C. Reichert, H. Meyer, C. Von Daniels, The makran accretionary wedge: sediment thicknesses and ages and the origin of mud volcanoes, Marine Geology 185 (2002) 219-232.

[27] W. D. Page, J. N. Alt, L. S. Cluff, G. Plafker, Evidence for the recurrence of large-magnitude earthquakes along the makran coast of iran and pakistan, Tectonophysics 52 (1979) 533-547.

[28] J. Reyss, P. Pirazzoli, A. Haghipour, C. Hatte, M. Fontugne, Quaternary marine terraces and tectonic uplift rates on the south coast of iran, Geological Society, London, Special Publications 146 (1999) 225-237.

[29] G. L. Smith, L. C. McNeill, K. Wang, J. He, T. J. Henstock, Thermal structure and megathrust seismogenic potential of the makran subduction zone, Geophysical Research Letters 40 (2013) 1528-1533.

[30] O. Skarpnes, Skinnemoen, J. Scotchmer, Nioc-statoil joint exploration study oman sea, Unpublished NIOC-Statoil Report 1 (2003) 154.

[31] C. H. Dix, Seismic prospecting for oil, Harper New York, 1952.

[32] M. Mokhtari, I. A. Fard, K. Hessami, Structural elements of the makran region, oman sea and their potential relevance to tsunamigenisis, Natural hazards 47 (2008) 185-199.

[33] J. Harms, H. Cappel, D. Francis, The makran coast of pakistan: its stratigraphy and hydrocarbon potential, Marine geology and oceanography of Arabian Sea and coastal Pakistan 3 (1984) 27. 
[34] A. Dolati, Stratigraphy, structural geology and low-temperature thermochronology across the Makran accretionary wedge in Iran, Ph.D. thesis, ETH Zurich, 2010.

[35] N. Ellouz-Zimmermann, E. Deville, C. Müller, S. Lallemant, A. Subhani, A. Tabreez, Impact of sedimentation on convergent margin tectonics: Example of the makran accretionary prism (pakistan), in: Thrust Belts and Foreland Basins, Springer, 2007, pp. 327-350.

[36] J. P. Platt, J. K. Leggett, Stratal extension in thrust footwalls, makran accretionary prism: implications for thrust tectonics, AAPG Bulletin 70 (1986) $191-203$.

[37] M. Prins, G. Postma, G. J. Weltje, Controls on terrigenous sediment supply to the arabian sea during the late quaternary: the makran continental slope, Marine Geology 169 (2000) 351-371.

[38] X. Yang, F. J. Peel, L. C. McNeill, D. J. Sanderson, Comparison of foldthrust belts driven by plate convergence and gravitational failure, Earth-Science Reviews (2020) 103136.

[39] C. Dahlstrom, Balanced cross sections, Canadian Journal of Earth Sciences 6 (1969) 743-757.

[40] F. Dahlen, J. Suppe, D. Davis, Mechanics of fold-and-thrust belts and accretionary wedges: Cohesive coulomb theory, Journal of Geophysical Research: Solid Earth 89 (1984) 10087-10101.

[41] F. Dahlen, Noncohesive critical coulomb wedges: An exact solution, Journal of Geophysical Research: Solid Earth 89 (1984) 10125-10133.

[42] G. P. Hayes, G. L. Moore, D. E. Portner, M. Hearne, H. Flamme, M. Furtney, G. M. Smoczyk, Slab2, a comprehensive subduction zone geometry model, Science 362 (2018) 58-61. 
[43] J. Salençon, De l'élasto-plasticité au calcul à la rupture, Editions Ecole Polytechnique, 2002.

[44] D. Chandrasekharaiah, L. Debnath, Continuum mechanics (new york: Academic) (1994).

[45] B. Maillot, Y. M. Leroy, Kink-fold onset and development based on the maximum strength theorem, Journal of the Mechanics and Physics of Solids 54 (2006) 2030-2059.

[46] A. K. Kuncoro, N. Cubas, S. C. Singh, M. Etchebes, P. Tapponnier, Tsunamigenic potential due to frontal rupturing in the sumatra locked zone, Earth and Planetary Science Letters 432 (2015) 311-322.

[47] J. Byerlee, Friction of rocks, in: Rock friction and earthquake prediction, Springer, 1978, pp. 615-626.

[48] K. Wang, S. L. Bilek, Do subducting seamounts generate or stop large earthquakes?, Geology 39 (2011) 819-822.

[49] N. Kukowski, T. Schillhorn, K. Huhn, U. von Rad, S. Husen, E. R. Flueh, Morphotectonics and mechanics of the central makran accretionary wedge off pakistan, Marine Geology 173 (2001) 1-19.

[50] N. Brantut, R. Han, T. Shimamoto, N. Findling, A. Schubnel, Fast slip with inhibited temperature rise due to mineral dehydration: Evidence from experiments on gypsum, Geology 39 (2011) 59-62.

[51] D. Faulkner, T. Mitchell, J. Behnsen, T. Hirose, T. Shimamoto, Stuck in the mud? earthquake nucleation and propagation through accretionary forearcs, Geophysical Research Letters 38 (2011).

[52] J.-Y. Collot, W. Agudelo, A. Ribodetti, B. Marcaillou, Origin of a crustal splay fault and its relation to the seismogenic zone and underplating at the 
erosional north ecuador-south colombia oceanic margin, Journal of Geophysical Research: Solid Earth 113 (2008).

[53] D. Melnick, M. Moreno, M. Motagh, M. Cisternas, R. L. Wesson, Splay fault slip during the m w 8.82010 maule chile earthquake, Geology 40 (2012) 251254.

[54] M. Farías, D. Comte, S. Roecker, D. Carrizo, M. Pardo, Crustal extensional faulting triggered by the 2010 chilean earthquake: The pichilemu seismic sequence, Tectonics 30 (2011).

[55] T. Tsuji, Y. Ito, M. Kido, Y. Osada, H. Fujimoto, J. Ashi, M. Kinoshita, T. Matsuoka, Potential tsunamigenic faults of the 2011 off the pacific coast of tohoku earthquake, Earth, planets and space 63 (2011) 58.

[56] K. Imanishi, R. Ando, Y. Kuwahara, Unusual shallow normal-faulting earthquake sequence in compressional northeast japan activated after the 2011 off the pacific coast of tohoku earthquake, Geophysical Research Letters 39 (2012).

[57] A. Bécel, D. J. Shillington, M. Delescluse, M. R. Nedimović, G. A. Abers, D. M. Saffer, S. C. Webb, K. M. Keranen, P.-H. Roche, J. Li, et al., Tsunamigenic structures in a creeping section of the alaska subduction zone, Nature Geoscience 10 (2017) 609.

[58] D. McKenzie, J. Jackson, Tsunami earthquake generation by the release of gravitational potential energy, Earth and Planetary Science Letters 345 (2012) $1-8$.

[59] S. P. Gulick, J. A. Austin, L. C. McNeill, N. L. Bangs, K. M. Martin, T. J. Henstock, J. M. Bull, S. Dean, Y. S. Djajadihardja, H. Permana, Updip rupture of the 2004 sumatra earthquake extended by thick indurated sediments, Nature Geoscience 4 (2011) 453-456. 